\title{
Batı Nil Virüsü Enfeksiyonuna Sekonder Gelişen Akut Demiyelinizan Polinöropati Olgusu
}

\author{
A Case of Acute Demyelinating Polyneuropathy Secondary \\ to West Nile Virus Infection \\ Yonca Ünlübaş, Abdulkadir Tunç, Murat Alemdar, Dilcan Kotan \\ Sakarya Üniversitesi, Sakarya Eğitim ve Araştırma Hastanesi, Nöroloji Kliniği Sakarya/Türkiye \\ Yazışsma Adresi / Correspondence: \\ Abdulkadir Tunç \\ Sakarya Üniversitesi, Sakarya Eğitim ve Araştırma Hastanesi, Nöroloji Kliniğgi \\ T: +905545144524 E-mail: drkadirtunc@hotmail.com \\ Geliṣ Tarihi / Received : 13.01.2019 Kabul Tarihi / Accepted : 25.02.2019
}

Öz

Batı Nil virüsü, asemptomatik bir klinik tablodan ağır ensefalit ve menenjite varan genis bir klinik varyasyonla prezente olabilir. Akut demiyelinizan polinöropati birlikteliği çok nadir bildirilmiştir. 60 yaş erkek hasta bilinç bozukluğu, kol ve bacaklarda güçsüzlük şikayetleri ile başvurdu. Kliniği, laboratuvar, beyin omurilik sıvısı ve elektrofizyoloji bulguları ön planda Guillain Barre sendromu ile uyumlu idi. Ateş, bilinç bozukluğu ve spastisite gibi atipik bulguların eșlik etmesi nedeniyle detaylı araștırılan olguda serum BN virüsü IgM testi pozitif bulundu. Türkiye’den bildirilen ilk olgu olması nedeniyle sunulmaya değer görüldü. ( Sakarya Tip Dergisi 2019, 9(1):160-163)

Anahtar Batı Nil virüsü; Guillain Barre sendromu; polinöropati

kelimeler

West Nile virus can lead to a wide range of clinical symptoms from asymptomatic disease to severe meningitis and encephalitis. The association of acute demyelinating polyneuropathy is rarely reported. A 60-year-old male patient presented with complaints of impaired consciousness and weakness in his arms and legs. Clinical findings, laboratory, cerebrospinal fluid and electrophysiology findings were consistent with Guillain Barre syndrome. Serum BN virus IgM test was found to be positive in the patient who was investigated because of atypical symptoms such as fever, impaired consciousness and spasticity. Our study was seen worthy to be presented due to the first case reported from Turkey (Sakarya Med J 2019, 9(1):160-163)

Key words West Nile virus; Guillain-Barre syndrome; polyneuropathy 


\section{Giriş}

Batı Nil (BN) virüsü, Japon ensefalit virüsü antijenik kompleksinin bir üyesi olup asemptomatik bir klinik tablodan ağır ensefalit ve menenjite varan geniş bir klinik varyasyonla prezente olabilir. ${ }^{1,2}$ Akut enfeksiyondan sonra, birçok hastada halsizlik, yorgunluk, hafıza kaybı, baş ağrısı ve denge sorunları gibi semptomlar görülür. ${ }^{3}$ Hastaların \%25' inde BN ateşi gelirken nöroinvaziv tutulum 150 ile 250 hastada bir görülür. ${ }^{4}$ Nöroinvaziv tutulum ateş ile birlikte menenjit, ensefalit, flask paralizi veya bunların bir arada olabildiği mikst formlara neden olur. ${ }^{2}$ Mortalite yaklaşık \%10 olarak bildirilmiştir. ${ }^{5}$ Literatürde $\mathrm{BN}$ virüsü enfeksiyonu sonrası akut polinöropati tablosu gelişen nadir vakalar bildirilmiştir. ${ }^{6,7} \mathrm{Bu}$ yazıda, Guillain Barre Sendromu (GBS) benzeri klinik ile başvuran ve takiplerinde $\mathrm{BN}$ virüsü pozitifliği saptanan, tedaviye dirençli çok nadir bir olgu sunulup literatür eşliğinde tartışılması amaçlandı.

\section{OLGU SUNUMU}

60 yaş erkek hasta bilinç bozukluğu, kol ve bacaklarda güçsüzlük şikayetleri ile acil servisimize getirildi. Öyküsünden fındık tarlasında çalıştıktan 10 gün sonra yüzde kızarma, ateş, halsizlik, uykuya meyil sonrasında kol ve bacaklarda güç kaybı şikayetinin 2 gün içerisinde hızlıca geliştiği öğrenildi. Özgeçmişinde ve soy geçmişinde özellik saptanmadı. Alışkanlıklarının sorgusu da normaldi. Sistemik muayenesinde $38.5^{\circ} \mathrm{C}$ ateşi dışında belirgin patolojik bulgu izlenmedi. Nörolojik muayenesinde şuuru uykuya meyilli, sözel uyarana yöneliyordu, verbal yanıt yoktu. Pupilleri izokorik, gözler her yöne serbest hareketli, pupilla 1şık refleksi +/+ idi. Şüpheli ense sertliği mevcuttu ancak meningeal irritasyon bulgusu saptanmadı. Dört esktremitede kas gücü 3/5 düzeyinde idi. Tonus hafif artmıştı (hafif spastisite+) ve üstte ve altta derin tendon refleksleri (DTR) alınamadı. Taban cildi refleksi bilateral fleksör yanıtlıdı. Göz dibi incelemesi normaldi. Beyin bilgisayarlı tomografi ve magnetik rezonans görüntülemelerinde patolojik bulgu saptanmaması üzerine hastaya lomber ponksiyon yapıldı. Beyin omurilik sıvısı (BOS) basıncı normaldi. BOS protein düzeyi artmıştı (189 mg/dl). Hücre sayımı normaldi. Saat- ler içerisinde kan oksijen saturasyonu düzeyi düşen hasta entübe edilerek nöroloji yoğun bakımına alındı. Detaylı laboratuvar tetkikleri, BOS’ta viral ve bakteriyel panel taramaları, toksik-paraneoplastik incelemeler ve gangliozid paneli yatış süresince incelendi. Kliniği ve BOS bulgular1 GBS ile uyumlu olduğundan 5 gün süre ile $0.4 \mathrm{gr} / \mathrm{kg} /$ gün dozunda intravenöz immunglobulin (IVIG) tedavisi uygulandi. Birinci haftanın sonunda yapilan elektrofizyolojik incelemelerinde saptanan bulgular üstte ve altta aksonal ve demiyelinizan tutulum özellikleri gösteren ve ileti bloklarının eşlik ettiği bir polinöropati sendromu ile uyumluydu. Hastanın serumda gönderilen $\mathrm{BN}$ virüsü IgM testi pozitif sonuçlandı. Literatürde destek tedavisi ve IVIG dışında önerilere rastlamamamıza karşılık ağır klinik seyir ve IVIG yanıtsızlığı nedeniyle gün aşırı 7 seans plazmaferez uygulandı. Minimal kas güçlerinde düzelme olsa da dalgalı seyreden kliniği ve araya giren enfeksiyon ve elektrolit bozuklukları sonrası hasta 52. gününde exitus olarak kabul edildi.

\section{TARTIŞMA}

$\mathrm{BN}$ virüsü, çeşitli konak türlerinde merkezi sinir sistemini infekte edebilmesi ve ciddi nörolojik tutuluma yol açabilmesi nedeniyle dünya çapında öneme sahiptir. Nöroinvaziv tutulumda ileri yaşlarda ensefalit, çocukluk çağında menenjitin daha ön planda olduğu bildirilmiştir.2,5,8 Ensefalit tablosu ılımlı, kendini sınırlayan konfüzyonel bir durumdan ağır ensefalopati, koma ve ölüme varan değişkenlikte görülebilir. Diğer nörolojik belirtiler arasında özellikle üst ekstremitelerde kaba tremor ve myoklonus, ayrıca rijidite, postural instabilite ve bradikinezi gibi parkinsonyen bulgular yer alır.8 Olgumuzda bilinç bozukluğu, şüpheli ense sertliği ve ateş bir menenjit veya ensefalit tablosu düşündürmekte idi. Dört ekstremitede azalan kas gücü ve artan tonus, $\mathrm{BN}$ virüsünün nöroinvaziv tutulumu ile uyumlu idi.

Literatürde BN virüsü sonrası 48 saat içerisinde hızlı gelişen alt ekstremitelerde asimetrik güçsüzlük, (menenjit/ ensefalit birlikteliği değişken) ile seyreden akut flask pa- 
ralizi ve anterior horn tutulumu (poliomyelit benzeri) bildirilmiştir. ${ }^{7}$ Buna karşılık, BN virüsü enfeksiyonu sonrası GBS sadece bir olguda tanımlanmıştır. ${ }^{6}$ Olgumuzda GBS tanısı akut tetraparezi, DTR kaybı, BOS protein yüksekliği ve elektrofizyolojik çalışmalar sonrası konuldu.

$\mathrm{BN}$ virüsü enfeksiyonu tanısında serumda veya BOS’ta IgM antikorlarının saptanması çoğu vakada tanı için yeterlidir. ${ }^{3,5}$ Artmış BOS protein düzeyi ( $\left.<150 \mathrm{mg} / \mathrm{dL}\right)$, normal veya azalmış glukoz düzeyi ve pleositozis $(<500$ hüre/ microL, lenfosit hakim) tanımlanmıştır. BOS’un sitolojik incelemesinde, plazmasitoid lenfositler veya Mollaret hücrelerini andıran büyük monositik hücreler bulunabilir. ${ }^{9}$ Olgumuzda BOS protein yüksekliği başta sadece GBS ile ilişkilendirilmişti. Takipte tedavi yanıtsızlığı, BN virüsü IgM pozitifliği ve diğer $\mathrm{BN}$ virüsü nöroinvaziv tutulum bulguları söz konusu protein yüksekliğinin de BN virüsü enfeksiyonuna sekonder olduğunu göstermiştir.

Literatürde mortalite için risk faktörleri arasında, ileri yaş, erkek cinsiyet, ağır kas güçsüzlüğünün eşlik ettiği ensefalit kliniği, bilinç bozukluğu, diyabet, kardiyovasküler hastalıklar, hepatit C, alkol kullanımı, immunsupresyon, quadripleji ve respiratuvar tutulum bildirilmiştir., ${ }^{3,4}$ Olgumuzda kötü prognoz bulgularının çoğu mevcuttu.

Tedavide primer olarak destek tedavisi önerilmektedir. IVIG tedavisinin potansiyel etkinliği Planitzer ve arkadaşlarının yaptığı çalışmada bildirilmiştir. ${ }^{10}$ Bizim hastamızda destek tedavisi, hızlı entübasyon ve IVIG uygulandı. Tedavi yanıtsızlığı nedeniyle plazmaferez de verilmesine karşın hasta fayda görmedi.

Sonuç olarak GBS tablosu ile prezente olan hastalarda ve ateş, bilinç bozukluğu, rijidite gibi atipik bulguların eşlik etmesi durumunda, BOS’ta hücre olmasa bile enfeksiyöz taramalara $\mathrm{BN}$ virüsü dahil edilmelidir. Literatürde BNVGBS birlikteliği nadir bildirildiğinden ve bu birlikteliğin Türkiye'den bildirileceği ilk olgu olması nedeniyle sunulmaya değer görülmüştür. 
Sakarya Tip Dergisi 2019;9(1):160-163

\section{Kaynaklar}

1. Gubler DI. The continuing spread of West Nile virus in the western hemisphere. Clin Infect Dis. 2007 Oct 15;45(8):1039-1046.

2. Davis LE, DeBiasi R, Goade DE, Haaland KY, Harrington JA, Harnar JB, et al. West Nile virus neuroinvasive disease. Ann Neurol. 2006 Sep;60(3):286-300

3. Loeb M, Hanna S, Nicolle L, Eyles J, Elliott S, Rathbone M, et al. Prognosis after West Nile virus infection. Ann Intern Med. 2008 Aug 19;149(4):232-241.

4. Watson JT, Pertel PE, Jones RC, Siston AM, Paul WS, Austin CC, et al. Clinical characteristics and functional outcomes of West Nile Fever. Ann Intern Med. 2004 Sep 7;141(5):360365

5. Petersen LR, Brault AC, Nasci RS. West Nile virus: review of the literature. JAMA. $2013 \mathrm{Jul}$ 17;310(3):308-315.

6. Ahmed S, Libman R, Wesson K, Ahmed F, Einberg K. Guillain-Barre 'syndrome: an unusual presentation of West Nile virus infection. Neurology. 2000;55: 144-146.
7. Alker A. West Nile virus-associated acute flaccid paralysis. BMJ Case Rep. 2015 May 2;2015. pii: bcr2014206480.

8. Sejvar JJ, Haddad MB, Tierney BC, Campbell GL, Marfin AA, Van Gerpen JA, et al. Neurologic manifestations and outcome of West Nile virus infection. JAMA. 2003 Jul 23;290(4):511-515.

9. Tyler KL, Pape J, Goody RJ, Corkill M, Kleinschmidt-DeMasters BK. CSF findings in 250 patients with serologically confirmed West Nile virus meningitis and encephalitis. Neurology. 2006 Feb 14;66(3):361-365.

10. Planitzer CB, Modrof J, Kreil TR. West Nile virus neutralization by US plasma-derived immunoglobulin products. J Infect Dis. 2007; 196: 435-440. 